\title{
Decomposition of Standing Litter Biomass in Newly Constructed Wetlands Associated with Direct Effects of Sediment and Water Characteristics and the Composition and Activity of the Decomposer Community Using Phragmites australis as a Single Standard Substrate
}

\author{
Ciska C. Overbeek ${ }^{1,2}$ (D) $\cdot$ Harm G. van der Geest ${ }^{1} \cdot$ E. Emiel van Loon ${ }^{3} \cdot$ Wim Admiraal $^{1}$
}

Received: 1 December 2017 / Accepted: 13 September 2018 / Published online: 30 October 2018

(C) The Author(s) 2018

\begin{abstract}
In a large-scale field experiment in 18 basins in a three-year old constructed wetland ( 6 ha) in the Netherlands, we analyzed a wide range of environmental variables, grouped into variable groups, to determine the combined direct effect of the environmental variables and the resulting decomposer community on decomposition rates of standing litter biomass in newly constructed wetlands. The variability among the experimental units could only to a limited degree be explained by linear combinations of all 54 possible predictor variables (30 and 23\% of variation explained after 6 and 12 months of decomposition). Moreover, models for decomposition after 6 months could not predict decomposition after 12 months. The poor predictions by our models are probably due to (sometimes large) variations in the predictor variables but small differences in decomposition rates between the different basins. Based on our results it seems that decomposition of standing litter biomass in newly constructed wetlands is relatively uniform when considered in time and space, with low explanatory power by variable groups from biotic and abiotic variables. Normally one would expect differences in decomposition rates with differing environments, but counterintuitively in newly constructed wetlands these differences are small.
\end{abstract}

Keywords Phragmites australis · Decomposer community $\cdot$ In situ experiment $\cdot$ All-possible-subsets regression

\section{Introduction}

Most newly constructed wetlands are used for water treatment and habitat restoration for wildlife (Fennessy et al. 1994;

Electronic supplementary material The online version of this article (https://doi.org/10.1007/s13157-018-1081-y) contains supplementary material, which is available to authorized users.

Ciska C. Overbeek

c.c.overbeek@uva.nl

1 Freshwater and Marine Ecology, Institute for Biodiversity and Ecosystem Dynamics, University of Amsterdam, P.O. Box 94248, 1090 GE Amsterdam, the Netherlands

2 Present address: Nelen \& Schuurmans, Zakkendragershof 34-44, 3511 AE Utrecht, the Netherlands

3 Theoretical and Computational Ecology, Institute for Biodiversity and Ecosystem Dynamics, University of Amsterdam, P.O. Box 94248, 1090 GE Amsterdam, the Netherlands
Vymazal 2007; Zhao et al. 2015). To understand the functioning of newly constructed wetlands in terms of nutrient cycling, it is important to quantify production and decomposition rates. However, most studies focus on aboveground plant production rather than on decomposition of this material (as indicator number of results in Web of Science topic search: "constructed wetland" - 3623, "constructed wetland" AND production AND (macrophyte OR plant OR vegetation OR biomass) - 240, "constructed wetland" AND decomposition AND (macrophyte OR plant OR vegetation OR biomass) 61). Furthermore, since newly constructed wetlands show large variability in both abiotic and biotic conditions, following successional patterns over time, the drivers of decomposition rates in these systems may differ from those in developed systems.

When designing and constructing new wetlands, one of the well-known driving forces for production and decomposition, i.e., nutrient availability, can be influenced by selecting specific types of sediment and water, for example rainwater with 
lower nutrient availability or more nutrient-rich water from nearby agricultural fields. A high availability of nutrients from surface water or eutrophic sediments potentially leads to high biomass production and higher availability of nutrients in the litter (Tanner 1996; Hoagland et al. 2001; Lee and Bukaveckas 2002; Fennessy et al. 2008; Trinder et al. 2009; Emsens et al. 2016a, b). However, decomposition rates will also be high (Rejmánková and Houdková 2006; Sarneel et al. 2010; Emsens et al. 2016a), since high plant tissue nutrient levels will increase decomposition (Serna et al. 2013) of the most easily degradable water-soluble compounds and nonlignified carbohydrates (Berg and Laskowski 2005). In contrast, high concentrations of $\mathrm{N}$ can also decrease decomposition rates of lignified carbohydrates and lignin, which are decomposed in later stages, due to their inhibiting effect on lignin degrading enzymes (Berg and Laskowski 2005). When environmental conditions are highly eutrophic, decomposition rates can become uncoupled from litter quality indicators (Emsens et al. 2016a, b), possibly coinciding with a shift in microbial decomposer community composition from a specialization in degradation of recalcitrant organic matter to dominance of opportunistic competitors (Moorhead and Sinsabaugh 2006).

This other important driving factor, the composition of the decomposer community of invertebrates and microorganisms, will also be influenced by the way in which a new wetland is designed. In newly constructed systems, macroinvertebrates colonize the area from the surroundings and will settle if suitable habitats are present (Stanczak and Keiper 2004; Stewart and Downing 2008). Over time, density and diversity will increase when the wetland habitats become more heterogeneous (Voshell and Simmons 1984; Christman and Voshell 1993; Heino 2000). Bacteria and fungi are functionally complementary and degrade different fractions of organic matter in different stages of succession (Findlay et al. 2002; Thormann et al. 2003; Fischer et al. 2006). Microbial community composition and activity can be influenced by litter nutrient availability and abiotic conditions (Trinder et al. 2009; Andersen et al. 2010; Straková et al. 2011), and can in turn influence food quality for macroinvertebrates (Boulton and Boon 1991; Whatley et al. 2014). Since both microbes and macroinvertebrates interact in the decomposition process (Hieber and Gessner 2002), changes in the functional community composition during different stages in succession after the construction of a new wetland need to be considered when studying decomposition rates in such systems.

Most studies focus on the effect of only a few variables on decomposition (e.g., Qualls and Richardson 2000; Aerts et al. 2005; Chimney and Pietro 2006; Álvarez and Bécares 2006; Sarneel et al. 2010; Voellm and Tanneberger 2014), mainly in developed, stabilized wetlands. However, since newly constructed wetlands show such large heterogeneity and variability in abiotic and biotic conditions, it is likely that multiple variables influence decomposition rates simultaneously or in interaction. Some studies do include the complexity of multiple variables in the field (Thullen et al. 2008), but mainly using artificial substrates like cotton strips (Harrison et al. 1988; Mendelssohn et al. 1999; Tiegs et al. 2013), thereby ignoring the chemical complexity of natural litter biomass. We hypothesize that the mineral composition of both sediment and water with the resulting sediment food quality, and the availability of micronutrients, macronutrients and trace elements in the sediment and water all influence decomposer community composition and activity (e.g., Heino 2000; Stewart and Downing 2008; Straková et al. 2011; Andersen et al. 2013; Whatley et al. 2014). Furthermore, we hypothesize that those abiotic and biotic factors influence decomposition rates of standing litter biomass (e.g., Fischer et al. 2006; Rejmánková and Houdková 2006; Thullen et al. 2008; Fennessy et al. 2008; Sarneel et al. 2010; König et al. 2014; Ping et al. 2017) both directly and indirectly through the indirect effect of abiotic conditions on litter quality (Fennessy et al. 2008; Sarneel et al. 2010; Emsens et al. 2016a, b). To be able to focus on the direct effects of abiotic conditions on aboveground decomposition rates and separate them from the indirect effects, this study used common reed (Phragmites australis) as a single standard substrate. To add to the existing knowledge, this study aims to (1.) determine the relative importance of sediment and water characteristics on the composition and activity of the decomposer community, and to (2.) determine the combined direct effect of the environmental variables and the resulting decomposer community on decomposition rates of standing litter biomass in newly constructed wetlands.

To meet this aim, we performed a large-scale field decomposition experiment in different basins at the Volgermeerpolder. This three-year old constructed wetland (6 ha) in the Netherlands targets peat formation and contains 27 basins with a range in substrates, water regimes, and resulting pioneer vegetation and decomposer communities. Fifty-four variables, of which 45 were abiotic and 9 biotic, were measured to determine which predictor variables, either combined in groups or separately, best explain functional decomposer community composition and activity as well as aboveground litter decomposition in newly constructed wetlands.

\section{Materials and Methods}

\section{Site Description}

All experiments were carried out in 2013-2014 in the Volgermeerpolder $\left(52^{\circ} 25^{\prime} 17^{\prime \prime} \mathrm{N} ; 4^{\circ} 59^{\prime} 35^{\prime \prime S}\right)$, the Netherlands, a newly constructed wetland on top of a former waste dump site that was completed in 2011. Multiple basins 
ranging from 550 to $1600 \mathrm{~m}^{2}$ were created in this wetland to initiate peat development on top of a sand-covered geomembrane. Basins were formed by clay dikes and the sand substrate in some basins was complemented with clay or organic sludge. The application of different mixtures of sand, clay and organic sludge resulted in a range of organic matter fractions in the sediments ( 0.01 to 0.23 , Fig. 1a, Table 1 and Online Resource 1) in the different basins. The 18 basins used in this study were fed either with rain water (collected in a dedicated basin), or with nutrient-rich surface water from surrounding agricultural fields. Water levels were kept at $60 \pm$ $15 \mathrm{~cm}$ above the sediment surface. As a result of the combination of different sediment mixtures with the two water regimes, the basins each developed a unique mineral composition with resulting sediment food quality and availability of micronutrients, macronutrients and trace elements. All experiments and measurements in this study were performed in 2013/2014, three years after the construction of the wetland was completed. During the initial years vegetation in the basins developed depending on the sediment and water composition. Basins with sand sediments remained mainly unvegetated or covered by submerged species $(77 \pm 7 \%$, mean \pm SD), with a helophyte coverage of only $14 \pm 6 \%$ after 3 years. Basins with addition of clay or organic sludge showed higher coverage by helophytes ( $40 \pm 23$ and $71 \pm 16 \%$, respectively). Typha angustifolia was the dominant species in basins with added clay sediment, covering around $26 \pm 21 \%$ of the basins, while Typha latifolia was the dominant species in
Fig. 1 Variation in selected response variables between basins in standing litter biomass decomposition experiment in the Volgermeerpolder, ranked according to sediment organic matter content. a) fraction organic matter, b) decomposer community with b1) Community Metabolic Diversity, b2) Average Well Color Development, b3) macroinvertebrate FFG distribution, c) aboveground litter remaining (fraction dry weight) with $\mathrm{c} 1)$ fraction remaining after 6 months and c2) fraction remaining after 12 months of decomposition. In all graphs one data point represents one measurement, except in b3) where it represents four measurements each
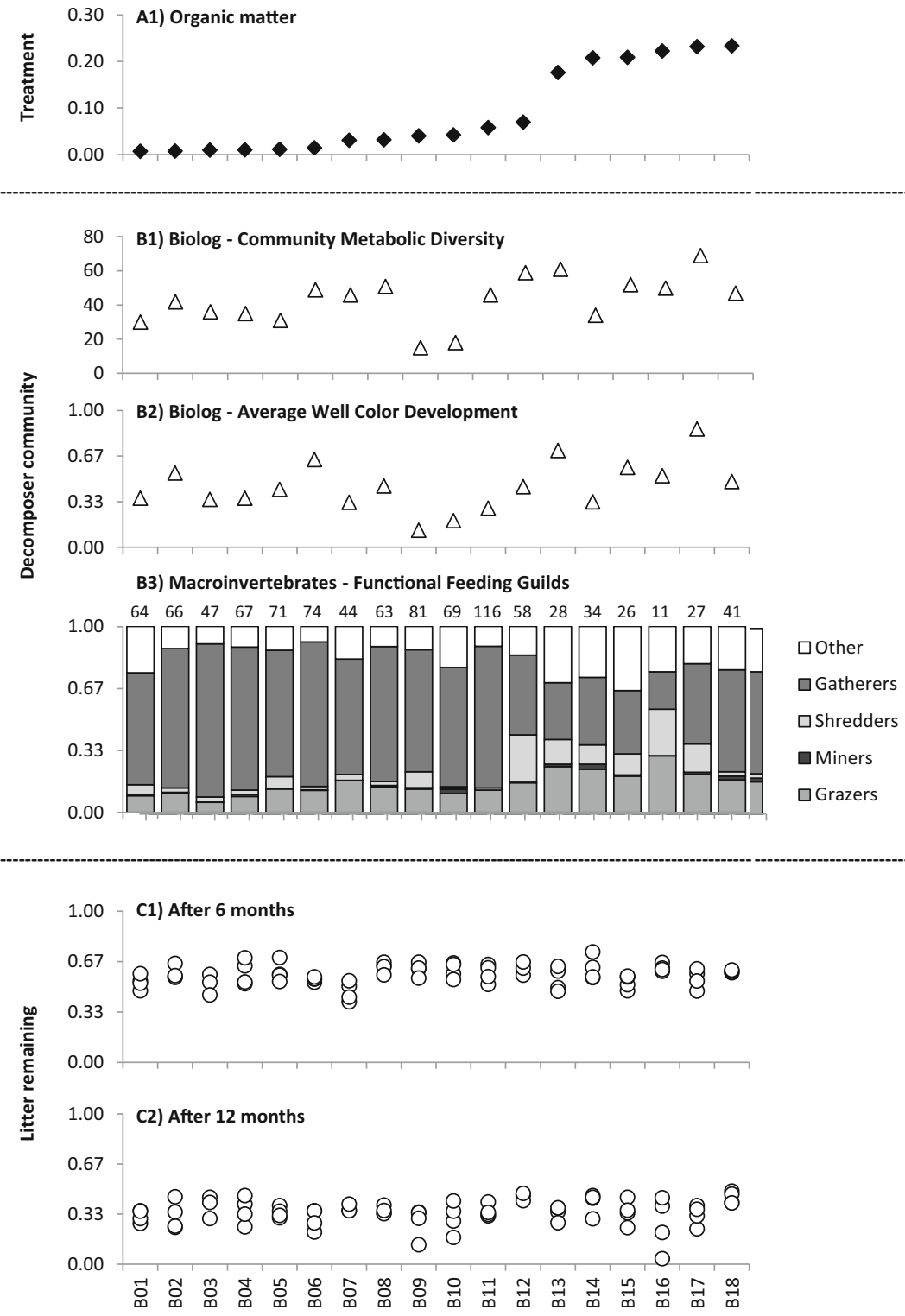
Table 1 Range in sediment and water quality variables $(10-90 \%$ percentiles (mean)) for basins in Volgermeerpolder $(n=18)$

\begin{tabular}{|c|c|c|c|c|c|c|c|c|c|}
\hline \multirow[b]{2}{*}{ Variable } & \multirow[b]{2}{*}{ Unit } & \multicolumn{4}{|c|}{ Surface water } & \multicolumn{4}{|c|}{ Pore water } \\
\hline & & $10 \%$ & - & $90 \%$ & (Mean) & $10 \%$ & - & $90 \%$ & (Mean) \\
\hline Temperature May & ${ }^{\circ} \mathrm{C}$ & 14.4 & - & 15.7 & $(14.9)$ & & & & \\
\hline Temperature November & ${ }^{\circ} \mathrm{C}$ & 7.3 & - & 7.9 & (7.6) & & & & \\
\hline Electrical conductivity & $\mu \mathrm{S} / \mathrm{cm}$ & 534 & - & 1026 & $(766)$ & & & & \\
\hline $\mathrm{pH}$ & - & 7.6 & - & 8.7 & $(8.2)$ & & & & \\
\hline Alkalinity & meq/l & 2.6 & - & 4.4 & (3.5) & 7.4 & - & 24.6 & $(16.2)$ \\
\hline $\mathrm{CO}_{2}$ & $\mu \mathrm{mol} / 1$ & 45 & - & 418 & $(164)$ & 2250 & - & 4371 & $(3137)$ \\
\hline $\mathrm{HCO}_{3}^{-}$ & $\mu \mathrm{mol} / 1$ & 1901 & - & 4205 & $(2710)$ & 7012 & - & 17994 & $(12653)$ \\
\hline $\mathrm{NO}_{3}^{-}$ & $\mu \mathrm{mol} / 1$ & 0.23 & - & 1.14 & $(0.56)$ & 0.07 & - & 3.47 & $(1.66)$ \\
\hline $\mathrm{NH}_{4}^{+}$ & $\mu \mathrm{mol} / 1$ & 2.1 & - & 11.0 & $(5.8)$ & 6.7 & - & 81.7 & $(43.8)$ \\
\hline Dissolved organic $\mathrm{N}$ & $\mu \mathrm{mol} / 1$ & 8.0 & - & 38.2 & $(21.5)$ & & & & \\
\hline Soluble reactive phosphorus & $\mu \mathrm{mol} / 1$ & 0.2 & - & 6.0 & $(2.1)$ & 0.8 & - & 21.2 & $(8.5)$ \\
\hline $\mathrm{K}^{+}$ & $\mu \mathrm{mol} / 1$ & 46 & - & 176 & (119) & 23 & - & 187 & $(100)$ \\
\hline $\mathrm{Na}^{+}$ & $\mu \mathrm{mol} / 1$ & 957 & - & 4508 & $(2662)$ & 797 & - & 3092 & $(2123)$ \\
\hline $\mathrm{Cl}^{-}$ & $\mu \mathrm{mol} / \mathrm{l}$ & 552 & - & 4521 & $(2481)$ & 408 & - & 3640 & (2029) \\
\hline $\mathrm{Ca}^{2+}$ & $\mu \mathrm{mol} / 1$ & 1613 & - & 2523 & $(2077)$ & 3341 & - & 9801 & $(6553)$ \\
\hline Total Fe & $\mu \mathrm{mol} / 1$ & 1 & - & 5 & (3) & 98 & - & 483 & $(219)$ \\
\hline Total Mn & $\mu \mathrm{mol} / 1$ & 1 & - & 5 & (3) & 40 & - & 200 & $(95)$ \\
\hline Total P & $\mu \mathrm{mol} / 1$ & 1 & - & 10 & (4) & 19 & - & 151 & $(87)$ \\
\hline \multirow[t]{2}{*}{ Total S } & $\mu \mathrm{mol} / 1$ & 627 & - & 2230 & $(1455)$ & 97 & - & 1754 & $(728)$ \\
\hline & & \multicolumn{4}{|c|}{ Sediment } & & & & \\
\hline Fraction organic matter & - & 0.01 & - & 0.23 & $(0.09)$ & & & & \\
\hline Olsen-P & $\mu \mathrm{mol} / 1 \mathrm{FW}$ & 77 & - & 206 & (146) & & & & \\
\hline Percentage $\mathrm{N}$ & $\mathrm{mg} / \mathrm{mg} \mathrm{DW}$ & 0.03 & - & 0.48 & $(0.23)$ & & & & \\
\hline Percentage $\mathrm{C}$ & $\mathrm{mg} / \mathrm{mg} \mathrm{DW}$ & 0.74 & - & 9.98 & $(4.58)$ & & & & \\
\hline $\mathrm{C}: \mathrm{N}$ ratio & - & 16.4 & - & 21.3 & $(19.3)$ & & & & \\
\hline Percentage S & $\mathrm{mg} / \mathrm{mg} \mathrm{DW}$ & 0.05 & - & 0.53 & $(0.22)$ & & & & \\
\hline
\end{tabular}

sediments with added organic sludge $(65 \pm 22 \%)$ (Harpenslager et al. 2018).

\section{Physico-Chemical Variables}

Starting three years after construction, various physicochemical characteristics of surface water (SW), pore water (PW) and sediment (SED) were measured several times in one year, as described in Overbeek et al. (2018, details in Online Resource 1).

Measurements of surface water temperature (T), electrical conductivity (EC) and $\mathrm{pH}$ were taken in October - December 2013 and 2014 and April - June 2014 at $10 \mathrm{~cm}$ below the water surface using a HQ40D portable meter (HACH-Lange, Tiel, the Netherlands). Surface water samples were taken in November 2013 and February, May, July and December 2014 and filtered before further analysis in the laboratory, using Whatman mixed cellulose ester filters ME24. Pore water samples were taken at the same time as surface water samples at
$15 \mathrm{~cm}$ depth in the sediment using vacuum syringes attached to ceramic soil moisture cups (Eijkelkamp, Giesbeek, the Netherlands). Alkalinity for surface water of unfiltered samples was determined by titration down to $\mathrm{pH} 4.2$ using an auto-burette with accurately determined titer (ABU901, Radiometer, Copenhagen, Denmark, or Metrohm 716 DMS Titrino, Metrohm Applikon, Herisau, Switzerland). Carbon dioxide $\left(\mathrm{CO}_{2}\right)$ and bicarbonate $\left(\mathrm{HCO}_{3}{ }^{-}\right)$were measured on an infrared gas analyser or high-temperature combustion total organic carbon (TOC) (IRGA, ABB Analytical, Frankfurt, Germany, or TOC-V CPH, Shimadzu, Kyoto, Japan), using unfiltered samples. Nitrate $\left(\mathrm{NO}_{3}{ }^{-}\right)$, ammonium $\left(\mathrm{NH}_{4}{ }^{+}\right)$, dissolved organic nitrogen (DON), soluble reactive phosphorus (SRP), potassium $\left(\mathrm{K}^{+}\right)$and sodium $\left(\mathrm{Na}^{+}\right)$were measured in filtered samples on an auto-analyser (AA3 system, Bran \& Luebbe, Norderstedt, Germany, or San ++ system, Skalar, Breda, the Netherlands). Chloride $\left(\mathrm{Cl}^{-}\right)$, calcium $\left(\mathrm{Ca}^{2+}\right)$, total iron (Fe), total manganese (Mn), total phosphorus $(\mathrm{P})$ and total sulphur $(\mathrm{S})$ were measured in filtered samples using 
inductively coupled plasma spectrometry (ICP-OES iCAP 6000, Thermo Fisher Scientific, Waltham, MA, USA, or Optima 8000DV, Perkin Elmer, Waltham, MA, USA).

Sediment samples were pooled from five subsamples per basin using the top $10 \mathrm{~cm}$ in February 2014 and the top $5 \mathrm{~cm}$ in June 2014 , and stored at $4{ }^{\circ} \mathrm{C}$ until further analyses. Fraction organic matter $(\mathrm{OM})$ was determined using loss on ignition (LOI, $4 \mathrm{~h}$ at $550^{\circ} \mathrm{C}$ ). Percentage nitrogen $(\mathrm{N})$, carbon (C) and sulphur (S) were measured on an elemental analyser (Carlo Erba NA1500, Thermo Fisher Scientific, Waltham, MA, USA, or Vario EL cube, Elementar, Hanau, Germany). Phosphorus readily available for uptake by vegetation (Olsen_P) was determined using extraction with $0.5 \mathrm{M}$ $\mathrm{NaHCO}_{3}$.

For all measured characteristics, except for temperature, yearly averages were calculated per basin since no seasonal differences were observed within basins. To give an indication of variation between basins yearly averages and percentiles of all basins combined are presented in Table 1 (see Online Resource 1 for values per basin).

\section{Decomposer Community}

As described in Overbeek et al. (2018), the decomposer community of the Volgermeerpolder has developed on top of the mineral sand bed from inocula introduced during the construction and during the pumping of water from the surrounding areas. Furthermore, the open basins serve as a refuge for waterfowl that may have introduced microorganisms and macroinvertebrates.

BIOLOG GN2 plates (BIOLOG Inc., Hayward, CA, USA) were used to determine functional microbial community composition and activity in the sediments three years after wetland construction. BIOLOG GN2 plates contain 95 wells with single simple carbon substrates and one control well (for an overview of all carbon sources see Garland and Mills 1991), specifically designed to make rapid community-level physiological profiles which best differentiate gram negative bacteria (Garland 1997). For each basin, the top $5 \mathrm{~cm}$ of five sediment samples taken in June 2014 were pooled together to get a representative sample per basin and stored at $4{ }^{\circ} \mathrm{C}$ until further processing the next day. Sediment samples were diluted with sterilized demi water to obtain a dilution of $1: 7$, shaken by hand for a minute to detach bacteria from sediment particles and centrifuged at $1000 \mathrm{~g}$ for $15 \mathrm{~min}$, after which the supernatant was diluted with sterilized demi water to a final dilution of 1:87 (adapted from Hench et al. 2004). BIOLOG plate wells were inoculated with $150 \mu \mathrm{l}$ bacterial suspension and incubated in the dark at $15{ }^{\circ} \mathrm{C}$ to simulate natural conditions. Absorption was measured at $590 \mathrm{~nm}$ every $24 \mathrm{~h}$ for 7 days (VersaMax microplate reader, Molecular devices,
Sunnyvale, USA). The absorbance for individual wells was corrected for background absorbance by subtracting absorbance of the control well and subsequently considering negative values as zero. Average Well Color Development (AWCD), a measure of microbial activity, was calculated according to Garland (1997), by averaging all 95 corrected response well absorbances. For Community Metabolic Diversity (CMD), a measure for microbial diversity, corrected absorbance values were converted to binary data (presence/absence) using a threshold absorbance of 0.25 (Garland 1996). The maximum slope in the sigmoidal response curve for AWCD as well as CMD appeared after three days of incubation, providing the highest distinctiveness between samples. Therefore, measurements taken after three days of incubation were used in further analyses.

Macroinvertebrates were sampled six months after the start of the experiment at the same time as the standing litter biomass (May 2014, see below) and identified to family-level, except for chironomids and oligochaetes, which were identified to tribe and class level, respectively. This taxonomic information was used to estimate the representation of functional feeding groups (FFGs). It was assumed that individuals found in the basins all originated from source populations in the surroundings, and that data on these source populations could therefore be used to determine the functional feeding guilds (FFGs) of the collected individuals in our study without determination to species level. To this purpose, FFGs were determined for all macroinvertebrate species found in an area stretching $5 \mathrm{~km}$ around the Volgermeerpolder in the years 2000-2015 (data provided by local water authority, http://hnk-water.nl) using the database from Schmidt-Kloiber and Hering (2015) (Online Resource 2). Subsequently, weighted averages, using the number of times a species was sampled by the water authority in all sampling locations at all times together as weight, were calculated for all FFG fractions per taxonomic family present in the surrounding area. For chironomids and oligochaetes, weighted averages were calculated per tribe and class, respectively (Online Resource 2). The calculated FFG distribution from the source population was assigned to the sampled individuals. When a sampled individual belonged to a taxonomic family which was not present in the source population, the FFG distribution was assumed to be equal to the one given by Schmidt-Kloiber and Hering (2015). Weighted averages of FFGs per sample were calculated accounting for number of individuals sampled per taxonomic level, without correction for size per individual. Gatherers (GAT), shredders (SHR), miners (MIN) and grazers (GRA) are all active in decomposition, therefore those four FFGs together were labeled as detritivores (DET). 


\section{Decomposition Experiment}

To separate the direct effects of environmental variables on decomposition rates of aboveground litter from the indirect effects of litter quality itself, we used common reed (Phragmites australis) as a single standard substrate. Common reed is a common wetland plant with easily distinguishable leaves and culms, therefore making it easy to construct quantifiable substrates for decomposition measurements. By constructing bundles of vegetation, keeping larger fragments together, instead of using litterbags (e.g., Petersen and Cummins 1974; Triska and Sedell 1976; McArthur et al. 1994), we avoided negative influences caused by using litterbags such as altering microclimates within the litterbags or exclusion of certain sizes of decomposer organisms (Boulton and Boon 1991; Bradford et al. 2002; Kurz-Besson et al. 2005; Bokhorst and Wardle 2013).

P. australis was collected from fresh stands growing in a ditch in the Volgermeerpolder at the end of the growing season in September 2013 and dried for several weeks at room temperature in the laboratory. Part of the litter was oven dried at $60{ }^{\circ} \mathrm{C}$ to determine the conversion factor between air-dry and oven-dry weight, as well as $\mathrm{C}, \mathrm{N}$ and $\mathrm{S}$ content of the litter $(n=4,45.0 \pm 0.2,1.7 \pm 0.1$ and $0.30 \pm 0.03 \%($ mean $\pm \mathrm{SD})$, respectively). Collected reed material consisted of equal amounts of stems and leaves and therefore both were tied together to $10 \mathrm{~g}$ bundles in equal proportions. The conversion factor between air-dry and oven-dry weight was used to calculate initial oven-dry weight of the air-dried bundles to be able to compare them to oven-dry weight at the time of collection. Litter bundles were placed in the field in November 2013 using a random block design with four blocks of $1 \times 1$ meter each placed in an area of $5.5 \times 5.5 \mathrm{~m}$. Each block contained two litter bundles for collection at two different times, resulting in eight litter bundles per basin in total. The bundles within a block were placed about $40 \mathrm{~cm}$ apart, and secured to the sediment using pins. Upon placement of the bundles, handling loss was determined to be $\sim 2 \%$. One bundle per block was retrieved after 6 months, while the other half was collected after 12 months by gently but quickly lifting the bundle from the sediment using a net to include macroinvertebrates. Litter bundles and macroinvertebrates were transported to the laboratory in sealed plastic bags and stored at $4{ }^{\circ} \mathrm{C}$ until further processing the next day, as described in Overbeek et al. (2018). Litter was gently rinsed and sieved using a mesh size of $1 \mathrm{~mm}$ to exclude sediment particles and dried for approximately three days at $60{ }^{\circ} \mathrm{C}$, after which remaining litter mass was determined. The weight difference between standing litter biomass at the start of the experiment (corrected for handling loss) and at time of retrieval was considered to be decomposition and expressed as fraction of the oven-dry start weight to get the fraction of decomposed aboveground litter (Frac_ $D_{6}$ and Frac $D_{12}$ for fraction aboveground litter loss after 6 and 12 months, respectively).

\section{Data Analysis}

\section{Predictor and Response Variables}

Linear models (multiple regression, assuming Gaussian errors) were formulated, fitted and validated to establish the relative importance of measured predictor variables for explaining response variables in the early stages of our newly constructed wetland (Burnham and Anderson 2002). To postprocess the models, all measured predictor variables were grouped in order to determine the relative importance of specific variable groups, defined as presence of these groups in the model ensemble, in explaining the response variable. Variables were grouped to water (SW), sediment $(\mathrm{PW}+$ SED), microbes (CMD + AWCD as measured by BIOLOG GN2 plates) or macroinvertebrates (abundance and FFGs, Online Resource 1), using yearly means for water and sediment variables. Next to these categories, predictor variables were also grouped in macronutrients (all SW and $\mathrm{PW} \mathrm{N}+\mathrm{P}$ ), sediment food quality (SED OM $+\mathrm{C}+\mathrm{N}+\mathrm{C} \_\mathrm{N}$ ), or other (see Online Resource 1 for an extensive list). To explain variation in (1.) functional community composition of microbes, (2.) activity of microbes, and (3.) fraction detritivores in macroinvertebrates, these three variables were separately taken as the response variable with all remaining separate variables from water and sediment variable groups after variable selection (see "Variable Selection" section and Online Resource $3 a)$ as potential predictor variables in model formulation. When using (4.) fraction aboveground litter loss after 6 months of decomposition or (5.) fraction aboveground litter loss after 12 months of decomposition as a response variable, all remaining separate variables from all variable groups after variable selection (see "Variable Selection" section and Online Resource 3a) were present as possible predictor variables.

\section{Validation}

The models were validated in two steps: (1.) by cross-validation, applying fitted models to predict unseen-data measured at the same time-period (both after 6 or 12 months of decomposition, resulting in $\mathrm{R}_{\text {val }}^{2}$ ), and (2.) by extrapolation, applying fitted models (based on data at 6 months of decomposition) to predict unseen-data at 12 months of decomposition (resulting in $\mathrm{R}_{\text {val } \_2 \text { with } t 1}^{2}$ ).

The different response variables were observed in different experimental layouts: macroinvertebrate and decomposition observations were laid out in 4 randomized blocks per basin while microbial data were observed only once per basin. For 
that reason the different response variables were validated differently: microbial data was validated using leave-one-out cross-validation (LOOCV), macroinvertebrate and decomposition data was validated using blocks for cross-validation: using three blocks to predict the fourth.

\section{Variable Selection}

Formulation of the linear models took place in two steps: (1.) selecting a subset from all predictor variables, using regression trees, and (2.) finding the best linear models using allpossible-subsets regression.

In the first step, regression trees were built using all available scaled predictors. For Frac_D and DET as response variables, where four-fold cross-validation was applied, the regression trees were based on the different combinations of three out of four blocks, after which all potentially important variables resulting from the four regression trees were combined into one list of potentially important predictor variables per response variable. For CMD and AWCD as response variables, a regression tree was fitted only once to the entire data set (see Online Resource 3a for an overview of the resulting potentially important predictor variables per response variable). In the second step, all possible combinations of up to four variables were made from the set with potentially important predictor variables, excluding combinations of variables with an absolute correlation higher than 0.7 , and including interactions between number of macroinvertebrate individuals and FFGs. Only those models with an AICdifference less than 2 from the model with the lowest AICvalue were considered adequate and retained. For the resulting model ensemble the importance and effect of each predictor variable was determined, as well as mean adjusted $R^{2}\left(R^{2}\right.$ adj $)$, with variable importance representing the fraction of models in the model ensemble in which the variable was present. The predictors were also aggregated into variable groups (Online Resource 1), and the relative frequency at which each variable group was represented in the model ensemble was used to express variable group importance.

All analyses were performed in R (R Core Team 2015), using functions from the packages plyr, reshape, rpart and ggplot2 (Wickham 2007; Wickham 2009; Wickham 2011; Therneau and Atkinson 2018).

\section{Results}

\section{Decomposer Community}

Functional microbial community composition varies between basins, with Community Metabolic Diversity (CMD) varying between 0.26 and 0.66 (mean 0.44$)$ (10-90\% percentiles,
Fig. $1 \mathrm{~b} 1$ and Table 2). For CMD as response variable, a model ensemble of 8 models was found with an adjusted $\mathrm{R}^{2}$ of 0.711 and cross-validated $\mathrm{R}^{2}$ of 0.598 (Table 2, Online Resource $3 b)$. Variables belonging to both water and sediment variable groups were present in all models (Fig. 2), with calcium in the surface water and phosphorus from the sediment readily available for uptake by vegetation both present in $88 \%$ of the models (see Table 2 for an overview of the importance and effect of predictor variables in predicting the response variable). Sediment food quality variables were present in all models as well, with either fraction organic matter, or percentage $\mathrm{N}$ or percentage $\mathrm{C}$ in the sediment present in each model. Macronutrients, including phosphorus from the sediment readily available for uptake by vegetation, were present in $88 \%$ of the models.

Microbial activity varies between basins, with Average Well Color Development (AWCD) varying between 26 and 60 (mean 43) (10-90\% percentiles, Fig. 1 b2 and Table 2). For AWCD as response variable, a model ensemble of 12 models was found with an adjusted $\mathrm{R}^{2}$ of 0.774 and cross-validated $\mathrm{R}^{2}$ of 0.704 (Table 2, Online Resource 3c). Like CMD, variables belonging to both water and sediment variable groups were used in all models (Fig. 2), with pore water alkalinity present in $83 \%$ of the models (Table 2). Either fraction organic matter, or percentage $\mathrm{N}$ or percentage $\mathrm{C}$ in the sediment were present in each model as sediment food quality variable, resulting in a combined presence of $100 \%$. Macronutrients were present in $75 \%$ of the models, with pore water $\mathrm{NH}_{4}{ }^{+}$present in $58 \%$.

In all basins in the Volgermeerpolder $82 \%$ of all macroinvertebrates are detritivores (63-97\%, 10-90\% percentiles, Table 2), with gatherers making up the largest fraction and miners a very low fraction of detritivores (Fig. 1b3). With an increasing fraction of organic matter in the sediment, the fraction of gatherers decreases, while the fraction of shredders, grazers and other FFGs increases. The number of individual macroinvertebrates per block is variable within basins and decreases with a higher fraction of sediment organic matter. Forty models were present in the model ensemble with fraction detritivores (DET) as the response variable, with an adjusted $R^{2}$ of 0.269 and a cross-validated $R^{2}$ of 0.218 (Table 2, Online Resource 3d). Water and sediment variable groups are present in $95 \%$ and $98 \%$ of the models, respectively (Fig. 2), with the sediment $\mathrm{C}: \mathrm{N}$ ratio present in $85 \%$ and surface water soluble reactive phosphorus present in $58 \%$ of the models (Table 2). Sediment food quality variables are present in $85 \%$ of the models, with sediment C:N ratio present in all those models. Macronutrients are present in all models, with either $\mathrm{P}$ or soluble reactive phosphorus in the surface water present in $83 \%$ of the models. When considering surface and pore water together, $\mathrm{P}$ and/or soluble reactive phosphorus are present in $90 \%$ of the models, while $\mathrm{N}$ is only present in $28 \%$. 
Table 2 Range in five microbial, macroinvertebrate and decomposition response variables (mean $(10-90 \%$ percentiles), $\mathrm{N})$ as measured in basins in the Volgermeerpolder, including number of models in model ensemble, adjusted $\mathrm{R}^{2}\left(\mathrm{R}^{2}\right.$ adj , mean $\left.\pm \mathrm{SD}\right)$, cross-validated $\mathrm{R}^{2}\left(\mathrm{R}_{\text {val }}^{2}\right.$, mean $\pm \mathrm{SD}$, using LOOCV for microbial data, and cross-validation using blocks for macroinvertebrate and decomposition data), and extrapolated $\mathrm{R}^{2}$ predicting unseen-data after 12 months of decomposition using fitted models based on data after 6 months of

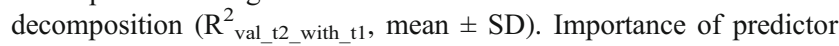
variable (sub)groups in model ensemble per response variable (importance representing the fraction of models in the model ensemble in which the variable (sub)group was present), with importance and effect of main predictor variables (present in more than $50 \%$ of model ensemble)

\begin{tabular}{ll}
$\begin{array}{l}\text { Response variable } \\
\text { mean }(10 \%-90 \%), \mathrm{N}\end{array}$ & $\begin{array}{l}\text { Predictor variable } \\
\text { (sub)group - importance }\end{array}$ \\
\hline
\end{tabular}

Community Metabolic Diversity (CMD)

$\begin{array}{ll}0.44(0.26-0.66), \mathrm{N}=18 & \text { Water }-100 \% \\ 8 \text { models in ensemble } & \text { Sediment }-100 \% \\ \mathrm{R}^{2} \text { adj }=0.711 \pm 0.009 & \text { Sediment food quality }-100 \% \\ \mathrm{R}_{\text {val }}^{2}=0.598 \pm 0.025 & \text { Macronutrients }-88 \%\end{array}$

Average Well Color Development (AWCD)

$\begin{array}{ll}43(26-60), \mathrm{N}=18 & \text { Water }-100 \% \\ 12 \text { models in ensemble } & \text { Sediment }-100 \% \\ \mathrm{R}_{\text {adj }}^{2}=0.774 \pm 0.008 & \text { Sediment food quality }-100 \% \\ \mathrm{R}_{\text {val }}^{2}=0.704 \pm 0.017 & \text { Macronutrients }-75 \%\end{array}$

Percentage detritivores (DET)

$\begin{array}{ll}82(63-97), N=72 & \text { Water }-95 \% \\ 40 \text { models in ensemble } & \text { Sediment }-98 \% \\ R_{\text {adj }}^{2}=0.269 \pm 0.007 & \text { Sediment food quality }-85 \% \\ R_{\text {val }}^{2}=0.218 \pm 0.018 & \text { Macronutrients }-100 \%\end{array}$

Main predictor variable - importance and effect

Predictor variable
(sub)group - importance

Main predictor variable - inportance and effect

Surface water $\mathrm{Ca}-88 \%+$

Sediment Olsen_P - $88 \%$ -

Either fraction organic matter, percentage $\mathrm{N}$ or percentage

$\mathrm{C}$ in sediment $-100 \%+$

Pore water alkalinity $-83 \%$ -

Either fraction organic matter, percentage $\mathrm{N}$ or percentage

$\mathrm{C}$ in sediment $-100 \%+$

Pore water $\mathrm{NH}_{4}{ }^{+}-58 \%+$

Surface water soluble reactive phosphorus $-58 \%$ -

Sediment C:N ratio - $85 \%$ -

Sediment C:N ratio $-85 \%$ -

Either surface water $\mathrm{P}$ or surface water soluble reactive phosphorus $-83 \%$ -

Surface or pore water $\mathrm{P}$ and/or surface or pore water soluble reactive phosphorus $-90 \%$ -

Percentage aboveground litter loss after 6 months (Frac_ $D_{6}$ )
$42(34-51), \mathrm{N}=70$
Water $-100 \%$
12 models in ensemble
Sediment $-67 \%$
$\mathrm{R}_{\text {adj }}^{2}=0.295 \pm 0.007$
Macroinvertebrate $-75 \%$
$\mathrm{R}_{\text {val }}^{2}=0.223 \pm 0.024$
Microbial - $0 \%$
$\mathrm{R}_{\text {val_t2_with_t1 }}^{2}=0.002 \pm 0.003$
Sediment food quality $-8 \%$
Macronutrients $-100 \%$

Surface water $\mathrm{NO}_{3}-100 \%$ -

Surface water S $-92 \%+$

Percentage aboveground litter loss after 12 months (Frac_ $\mathrm{D}_{12}$ )
$65(55-75), \mathrm{N}=69$
Water $-100 \%$
5 models in ensemble
Sediment $-100 \%$
$\mathrm{R}_{\text {adj }}^{2}=0.227 \pm 0.008$
Macroinvertebrate $-100 \%$
$\mathrm{R}_{\text {val }}^{2}=0.072 \pm 0.013$
Microbial - $0 \%$
Sediment food quality $-0 \%$
Macronutrients $-100 \%$

A positive effect of a predictor variable on the response variable indicates that the response variable will increase with an increase in the predictor variable, while a negative effect indicates a decrease in the response variable with an increase in the predictor variable. For an overview of the possible predictor variables present in variable (sub)groups, see Online Resource 1 


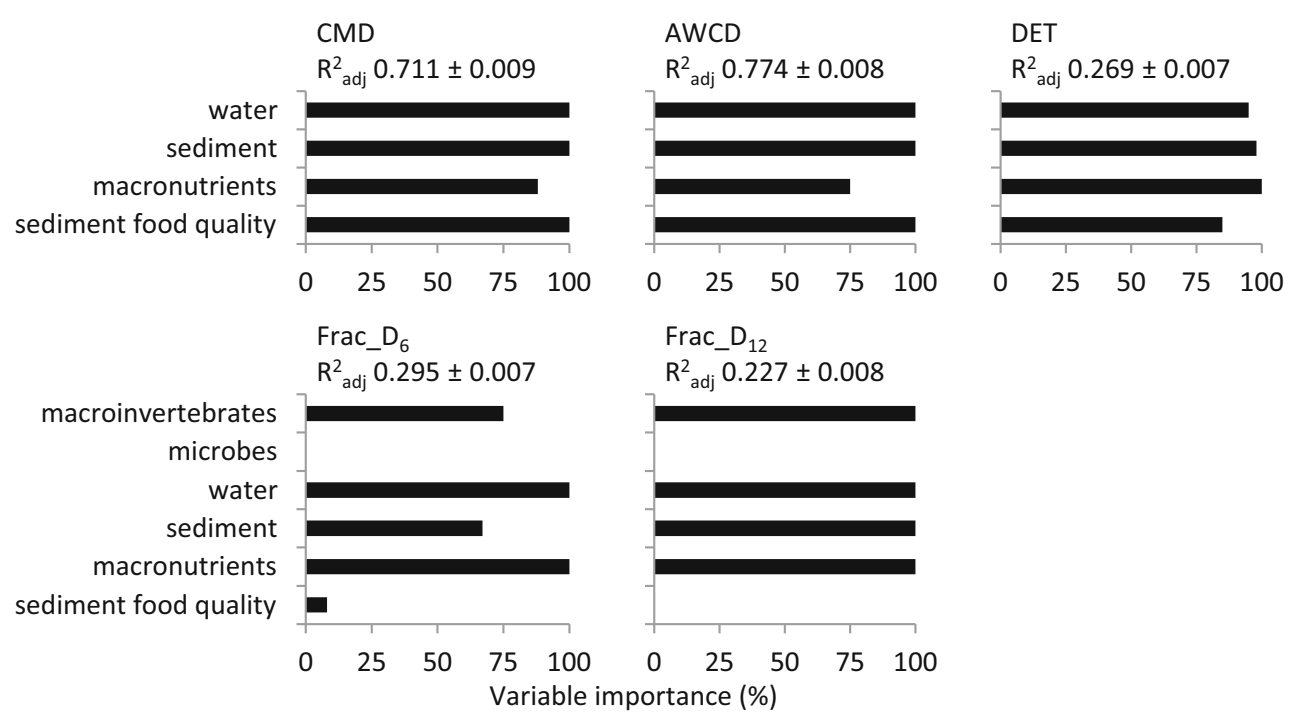

Fig. 2 Presence of predictor variable groups (variable importance (\%)) in model ensembles explaining response variables. Response variables: CMD) Community Metabolic Diversity for microbes, AWCD) Average Well Color Development for microbes, DET) fraction detritivores for

\section{Decomposition Experiment}

The fraction of remaining standing litter biomass decreases over time, with 58 and $35 \%$ litter remaining after 6 and 12 months of decomposition compared to starting values, respectively (49-66 and 25-45\%, respectively, both 10-90\% percentiles, Fig. 1c1 and c2, Table 2), with approximately $0.3 \%$ of the standing litter biomass being decomposed daily (see Online Resource 1 for exponential decay constants $(\mathrm{k})$ per basin per period). Variation between basins was relatively small, and comparable with variation within basins after both 6 and 12 months of decomposition. Furthermore, decomposition rates observed after 6 months of decomposition were not correlated to the rates observed after 12 months $(r=-0.076)$.

The model ensemble with Frac_D D $_{6}$ (fraction aboveground litter loss after 6 months) as response variable and all other measured variables (sediment, water, microbes, macroinvertebrates) as potential predictor variables consists of 12 models and has an adjusted $\mathrm{R}^{2}$ of 0.295 and a cross-validated $\mathrm{R}^{2}$ of 0.223 (Table 2, Online Resource 3e). Water variables are present in all models (Fig. 2), with surface water $\mathrm{NO}_{3}$ and $\mathrm{S}$ present in 100 and $92 \%$ of the models (Table 2). Sediment and macroinvertebrate variables are present in 67 and $75 \%$ of the models, respectively, while microbe variables are absent in all. Macroinvertebrate variables in the model ensemble comprise the number of individuals, the very small fraction of miners, and the interaction between them. The more dominant fractions of gatherers, shredders and grazers do not show up as predictor variables. Macronutrients are present in all models, with surface water $\mathrm{NO}_{3}$ present in $100 \%$ of the models. Sediment food quality variables are only present in $8 \%$ of the models. When predicting Frac $\mathrm{D}_{12}$ with the model macroinvertebrates, Frac_ $D_{6}$ ) fraction aboveground litter loss after 6 months of decomposition, Frac_ $\mathrm{D}_{12}$ ) fraction aboveground litter loss after 12 months of decomposition

ensemble from Frac_ $\mathrm{D}_{6}$, almost no variance could be explained $\left(R_{\text {val_t2_with_t1 }}^{2}=0.002\right.$, Table 2$)$.

Five models make up the model ensemble with Frac_ $D_{12}$ (fraction aboveground litter loss after 12 months) as response variable, with an adjusted $R^{2}$ of 0.227 and a cross-validated $R^{2}$ of 0.072 (Table 2, Online Resource 3f). Sediment, water and macroinvertebrate variables are all present in each model, while microbe variables are absent (Fig. 2). The macroinvertebrate variable group in the model ensemble is made up solely of grazers. For sediment, pore water $\mathrm{S}$ is present in all models. For water, either surface water $\mathrm{P}$ or soluble reactive phosphorus is present in all models, with surface water $\mathrm{P}$ present in $60 \%$. Macronutrients are present in all models, sediment food quality variables are absent in all models.

\section{Discussion}

Using linear models, we aimed to (1.) determine the relative importance of the abiotic conditions (in both the sediment and the water column) on the composition and activity of the decomposer community, and to (2.) determine the combined direct effect of the environmental variables and the resulting decomposer community on decomposition rates of standing litter biomass in newly constructed wetlands. To be able to focus on the direct effects of abiotic conditions on aboveground decomposition rates and separate them from the indirect effects, this study used common reed (Phragmites australis) as a single standard substrate. In the model ensembles we have presented here, variables related to the abiotic conditions in water and/or sediment were present in all models, indicating that the abiotic environment is an 
important factor influencing decomposition rates of standing litter biomass in newly constructed wetlands. Variables related to the presence of macroinvertebrates were present in most of our models, and are thus also recognized as a driving factor (partly) explaining decomposition rates. These observations corroborate with earlier findings on, for example, the effects of nutrients (Rejmánková and Houdková 2006; Sarneel et al. 2010; Emsens et al. 2016a) and invertebrates (König et al. 2014; Raposeiro et al. 2014) on decomposition rates in established wetland systems. However, sediment and water variables could only explain a small part of variation in the fraction of detritivores. Most likely, macroinvertebrates are still colonizing this newly constructed wetland, therefore their community composition is still variable and heterogeneous in time and space. In most constructed wetlands, especially when constructed basins are directly connected to other water bodies, community composition of macroinvertebrates will be similar to that in wetlands surrounding the area after a couple of years (Christman and Voshell 1993; Stanczak and Keiper 2004; Balcombe et al. 2005), while density and biomass can still show large variation (Stewart and Downing 2008), as was the case in this study. Mitsch and Wilson (1996) suggest that it may even take up to two decades before the functioning of the wetland can be determined after the initial stabilization phase. The fact that macroinvertebrates were only identified up to family level instead of species level might partially have led to the low fraction of variance that could be explained with the model ensemble, even though other studies showed that taxonomic resolution at the family level was adequate in determining the effect of environmental factors on macroinvertebrate communities (Bailey et al. 2001; Stewart and Downing 2008).

In contrast to sediment, water and macroinvertebrate variables, the composition of the microbial community was not an adequate predictor of decomposition in any of our models. This result can be explained in two ways; first, it could be that potentially important groups of bacteria involved in decomposition of more complex substrates like lignin and cellulose have been missed in our analysis, because those complex substrates are not present as carbon sources in BIOLOG GN2 plates (Garland and Mills 1991). Moreover, in soils and sediments bacteria interact physically and functionally with fungi in the process of litter degradation (Findlay et al. 2002; Thormann et al. 2003; Fischer et al. 2006; Hervé et al. 2016), specifically targeting the complex compounds using extracellular enzymes (Kirk and Farrell 1987; Thormann 2006). This part of the microbial community is also largely overlooked in the present study since BIOLOG GN2 plates are specifically designed for gram-negative bacteria (Garland and Mills 1991). Second, the microbial community composition and activity were sampled by combining five subsamples per basin, resulting in a sample of the total microbial community present per basin. This sampling procedure is accurate to determine the influence of sediment and water quality variables on microbial community composition and activity, but probably not to determine the influence of the microbial community composition and activity on decomposition rates of one artificially introduced litter type. On those litter bundles, the microbial communities will most likely have adapted to the conditions present, since microbial communities are very quick in adapting to new conditions (Trinder et al. 2009; Andersen et al. 2010; Flury and Gessner 2011; Weber and Legge 2011), resulting in a different microbial community composition and activity per litter bundle. Even though variables for microbial community composition and activity were absent in the model ensembles for decomposition, we cannot conclude that the microbial community has no influence on decomposition rates, since the microbial community composition and activity were not measured per litter bundle in this study.

Even though the variable groups sediment, water, macronutrients and macroinvertebrates were present in all or most of the linear models explaining decomposition rates, our models could only explain a small fraction (30 and 23\% after 6 and 12 months of decomposition, respectively) of the variability in decomposition rates for both measurement times. Moreover, the best models were inadequate for extrapolation: the model ensemble using data after 6 months of decomposition could not predict decomposition after 12 months. The poor predictions by our models, and the discrepancies between time points coincide with (sometimes large) variations in the predictor variables but simultaneously small differences in decomposition rates between the different basins. Two studies by Emsens et al. (2016a, b) found that decomposition rates decreased under nutrient rich conditions as compared to nutrient poor conditions, with more uniform decomposition rates between plant species under nutrient rich conditions. Also, decomposition rates were coupled with litter quality indicators under nutrient poor conditions, but under nutrient rich conditions this coupling was absent (Emsens et al. 2016a, b), probably due to a microbial community specialized in decomposition of recalcitrant organic matter (e.g. lignin) under nutrient limiting conditions, and a more opportunistic microbial community under nutrient rich conditions (Moorhead and Sinsabaugh 2006). Since the conditions in all of our basins were nutrient rich, this may have resulted in relatively uniform decomposition rates between basins and accompanying poor predictions by our models, as comparable to the results found by Emsens et al. (2016a, b).

Where in many studies effects of single factors on decomposition rates are quantified experimentally (e.g., Qualls and Richardson 2000; Aerts et al. 2005; Chimney and Pietro 2006; Álvarez and Bécares 2006; Sarneel et al. 2010; Voellm and Tanneberger 2014), our study, including a wide range of variables in a large in situ experiment, later grouped into variable groups, provides scientific insight in the complex interaction between driving factors on decomposition rates. Normally, 
one would expect differences in decomposition rates with differing environments, but counterintuitively in newly constructed wetlands these differences are small. However, even though single factors may influence decomposition rates in laboratory studies, we showed that decomposition rates of standing litter biomass in newly constructed wetlands seem to be relatively uniform in time and space, with low explanatory power by variable groups from water, sediment, microbes, macroinvertebrates, macronutrients and sediment food characteristics.

Acknowledgements We thank Sarah Faye Harpenslager for conducting part of the water and sediment analyses, and Arie Vonk, Seth van Heeringen and Arne Klink for their help with the fieldwork and identification of macroinvertebrates. Furthermore, we thank two anonymous reviewers, the editor and Sarah Faye Harpenslager for their valuable comments which helped to improve the manuscript. This research was funded by the Dutch Technology Foundation STW (PeatCap, project number 11264) and the municipality of Amsterdam.

Open Access This article is distributed under the terms of the Creative Commons Attribution 4.0 International License (http:// creativecommons.org/licenses/by/4.0/), which permits unrestricted use, distribution, and reproduction in any medium, provided you give appropriate credit to the original author(s) and the source, provide a link to the Creative Commons license, and indicate if changes were made.

\section{References}

Aerts R, van Logtestijn RSP, Karlsson PS (2005) Nitrogen supply differentially affects litter decomposition rates and nitrogen dynamics of sub-arctic bog species. Oecologia 146:652-658. https://doi.org/10. 1007/s00442-005-0247-5

Álvarez JA, Bécares E (2006) Seasonal decomposition of Typha latifolia in a free-water surface constructed wetland. Ecological Engineering 28:99-105. https://doi.org/10.1016/j.ecoleng.2006.05.001

Andersen R, Grasset L, Thormann MN, Rochefort L, Francez A-J (2010) Changes in microbial community structure and function following Sphagnum peatland restoration. Soil Biology and Biochemistry 42: 291-301. https://doi.org/10.1016/j.soilbio.2009.11.006

Andersen R, Chapman SJ, Artz RRE (2013) Microbial communities in natural and disturbed peatlands: a review. Soil Biology and Biochemistry 57:979-994. https://doi.org/10.1016/j.soilbio.2012. 10.003

Bailey RC, Norris RH, Reynoldson TB (2001) Taxonomic resolution of benthic macroinvertebrate communities in bioassessments. Journal of the North American Benthological Society 20:280-286. https:// doi.org/10.2307/1468322

Balcombe CK, Anderson JT, Fortney RH, Kordek WS (2005) Aquatic macroinvertebrate assemblages in mitigated and natural wetlands. Hydrobiologia 541:175-188. https://doi.org/10.1007/s10750-0045706-1

Berg B, Laskowski R (2005) Changes in substrate composition and rateregulating factors during decomposition. Litter decomposition: a guide to carbon and nutrient turnover. Elsevier Academic Press, pp $101-155$

Bokhorst S, Wardle DA (2013) Microclimate within litter bags of different mesh size: implications for the "arthropod effect" on litter decomposition. Soil Biology and Biochemistry 58:147-152. https:// doi.org/10.1016/j.soilbio.2012.12.001
Boulton A, Boon P (1991) A review of methodology used to measure leaf litter decomposition in lotic environments: time to turn over an old leaf? Marine and Freshwater Research 42:1-43

Bradford MA, Tordoff GM, Eggers T, Jones TH, Newington JE (2002) Microbiota, fauna, and mesh size interactions in litter decomposition. Oikos 99:317-323. https://doi.org/10.1034/j.1600-0706.2002. 990212.x

Burnham KP, Anderson DR (2002) Model selection and multimodel inference: a practical information-theoretic approach, 2nd edn. Springer Verlag, New York

Chimney MJ, Pietro KC (2006) Decomposition of macrophyte litter in a subtropical constructed wetland in South Florida (USA). Ecological Engineering 27:301-321. https://doi.org/10.1016/j.ecoleng.2006. 05.016

Christman VD, Voshell JR (1993) Changes in the benthic macroinvertebrate community in two years of colonization of new experimental ponds. Internationale Revue der gesamten Hydrobiologie und Hydrographie 78:481-491. https://doi.org/10.1002/iroh. 19930780403

Emsens W-J, Aggenbach CJS, Grootjans AP, Nfor EE, Schoelynck J, Struyf E, Diggelen R (2016a) Eutrophication triggers contrasting multilevel feedbacks on litter accumulation and decomposition in fens. Ecology 97:2680-2690. https://doi.org/10.1002/ecy.1482

Emsens W-J, Schoelynck J, Grootjans AP, Struyf E, van Diggelen R (2016b) Eutrophication alters Si cycling and litter decomposition in wetlands. Biogeochemistry 130:289-299. https://doi.org/10. 1007/s10533-016-0257-x

Fennessy MS, Cronk JK, Mitsch WJ (1994) Macrophyte productivity and community development in created freshwater wetlands under experimental hydrological conditions. Ecological Engineering 3:469484. https://doi.org/10.1016/0925-8574(94)00013-1

Fennessy MS, Rokosch A, Mack JJ (2008) Patterns of plant decomposition and nutrient cycling in natural and created wetlands. Wetlands 28:300-310. https://doi.org/10.1672/06-97.1

Findlay SEG, Dye S, Kuehn KA (2002) Microbial growth and nitrogen retention in litter of Phragmites australis compared to Typha angustifolia. Wetlands 22:616-625. https://doi.org/10.1672/02775212(2002)022[0616:MGANRI]2.0.CO;2

Fischer H, Mille-Lindblom C, Zwirnmann E, Tranvik LJ (2006) Contribution of fungi and bacteria to the formation of dissolved organic carbon from decaying common reed (Phragmites australis). Archiv für Hydrobiologie 166:79-97. https://doi.org/10.1127/00039136/2006/0166-0079

Flury S, Gessner MO (2011) Experimentally simulated global warming and nitrogen enrichment effects on microbial litter decomposers in a marsh. Applied and Environmental Microbiology 77:803-809. https://doi.org/10.1128/AEM.01527-10

Garland JL (1996) Analytical approaches to the characterization of samples of microbial communities using patterns of potential C source utilization. Soil Biology and Biochemistry 28:213-221. https://doi. org/10.1016/0038-0717(95)00112-3

Garland JL (1997) Analysis and interpretation of community-level physiological profiles in microbial ecology. FEMS Microbiology Ecology 24:289-300. https://doi.org/10.1111/j.1574-6941.1997. tb00446.x

Garland JL, Mills AL (1991) Classification and characterization of heterotrophic microbial communities on the basis of patterns of community-level sole-carbon-source utilization. Applied and Environmental Microbiology 57:2351-2359

Harpenslager SF, Overbeek CC, van Zuidam JP, Roelofs JGM, Kosten S, Lamers LPM (2018) Peat capping: natural capping of wet landfills by peat formation. Ecological Engineering 114:146-153. https:// doi.org/10.1016/j.ecoleng.2017.04.040

Harrison AF, Latter PM, Walton DWH (1988) Cotton strip assay: an index of decomposition in soils. Institute of Terrestrial Ecology, Grange-over-Sands, United Kingdom 
Heino J (2000) Lentic macroinvertebrate assemblage structure along gradients in spatial heterogeneity, habitat size and water chemistry. Hydrobiologia 418:229-242. https://doi.org/10.1023/A: 1003969217686

Hench KR, Sexstone AJ, Bissonnette GK (2004) Heterotrophic community-level physiological profiles of domestic wastewater following treatment by small constructed subsurface flow wetlands. Water Environment Research 76:468-473. https://doi.org/10.2175/ $106143004 X 151554$

Hervé V, Ketter E, Pierrat J-C, Gelhaye E, Frey-Klett P (2016) Impact of Phanerochaete chrysosporium on the functional diversity of bacterial communities associated with decaying wood. PLoS One 11: e0147100. https://doi.org/10.1371/journal.pone.0147100

Hieber M, Gessner MO (2002) Contribution of stream detrivores, fungi, and bacteria to leaf breakdown based on biomass estimates. Ecology 83:1026-1038. https://doi.org/10.1890/0012-9658(2002)083[1026: COSDFA]2.0.CO;2

Hoagland CR, Gentry LE, David MB, Kovacic DA (2001) Plant nutrient uptake and biomass accumulation in a constructed wetland. Journal of Freshwater Ecology 16:527-540. https://doi.org/10.1080/ 02705060.2001.9663844

Kirk TK, Farrell RL (1987) Enzymatic "combustion": the microbial degradation of lignin. Annual Review of Microbiology 41:465-501. https://doi.org/10.1146/annurev.mi.41.100187.002341

König R, Hepp LU, Santos S (2014) Colonisation of low- and highquality detritus by benthic macroinvertebrates during leaf breakdown in a subtropical stream. Limnologica - Ecology and Management of Inland Waters 45:61-68. https://doi.org/10.1016/j. limno.2013.11.001

Kurz-Besson C, Coûteaux M-M, Thiéry JM, Berg B, Remacle J (2005) A comparison of litterbag and direct observation methods of scots pine needle decomposition measurement. Soil Biology and Biochemistry 37:2315-2318. https://doi.org/10.1016/j.soilbio.2005.03.022

Lee AA, Bukaveckas PA (2002) Surface water nutrient concentrations and litter decomposition rates in wetlands impacted by agriculture and mining activities. Aquatic Botany 74:273-285. https://doi.org/ 10.1016/S0304-3770(02)00128-6

McArthur JV, Aho JM, Rader RB, Mills GL (1994) Interspecific leaf interactions during decomposition in aquatic and floodplain ecosystems. Journal of the North American Benthological Society 13:5767. https://doi.org/10.2307/1467265

Mendelssohn IA, Sorrell BK, Brix H, Schierup H-H, Lorenzen B, Maltby E (1999) Controls on soil cellulose decomposition along a salinity gradient in a Phragmites australis wetland in Denmark. Aquatic Botany 64 (3-4):381-398

Mitsch WJ, Wilson RF (1996) Improving the success of wetland creation and restoration with know-how, time, and self-design. Ecological Applications 6:77-83. https://doi.org/10.2307/2269554

Moorhead DL, Sinsabaugh RL (2006) A theoretical model of litter decay and microbial interaction. Ecological Monographs 76:151-174. https://doi.org/10.1890/0012-9615(2006)076[0151: ATMOLD]2.0.CO;2

Overbeek CC, van der Geest HG, van Loon EE, Klink AD, van Heeringen S, Harpenslager SF, Admiraal W (2018) Decomposition of aquatic pioneer vegetation in newly constructed wetlands. Ecological Engineering 114:154-161. https://doi.org/10. 1016/j.ecoleng.2017.06.046

Petersen RC, Cummins KW (1974) Leaf processing in a woodland stream. Freshwater Biology 4:343-368

Ping Y, Pan X, Cui L, Li W, Lei Y, Zhou J, Wei J (2017) Effects of plant growth form and water substrates on the decomposition of submerged litter: evidence of constructed wetland plants in a greenhouse experiment. Water 9. https://doi.org/10.3390/w9110827

Qualls RG, Richardson CJ (2000) Phosphorus enrichment affects litter decomposition, immobilization, and soil microbial phosphorus in wetland mesocosms. Soil Science Society of America Journal 64: 799. https://doi.org/10.2136/sssaj2000.642799x

R Core Team (2015) R: a language and environment for statistical computing. R Foundation for Statistical Computing, Vienna, Austria

Raposeiro PM, Martins GM, Moniz I, Cunha A, Costa AC, Gonçalves V (2014) Leaf litter decomposition in remote oceanic islands: the role of macroinvertebrates vs. microbial decomposition of native vs. exotic plant species. Limnologica - Ecology and Management of Inland Waters 45:80-87. https://doi.org/10.1016/j.limno.2013.10. 006

Rejmánková E, Houdková K (2006) Wetland plant decomposition under different nutrient conditions: what is more important, litter quality or site quality? Biogeochemistry 80:245-262. https://doi.org/10.1007/ s10533-006-9021-y

Sarneel JM, Geurts JJM, Beltman B, Lamers LPM, Nijzink MM, Soons MB, Verhoeven JTA (2010) The effect of nutrient enrichment of either the bank or the surface water on shoreline vegetation and decomposition. Ecosystems 13:1275-1286. https://doi.org/10. 1007/s10021-010-9387-5

Schmidt-Kloiber A, Hering D (2015) www.freshwaterecology.info - an online tool that unifies, standardises and codifies more than 20,000 European freshwater organisms and their ecological preferences. Ecological Indicators 53:271-282. https://doi.org/10.1016/j. ecolind.2015.02.007

Serna A, Richards JH, Scinto LJ (2013) Plant decomposition in wetlands: effects of hydrologic variation in a re-created Everglades. Journal of Environmental Quality 42:562-572. https://doi.org/10.2134/ jeq2012.0201

Stanczak M, Keiper JB (2004) Benthic invertebrates in adjacent created and natural wetlands in northeastern Ohio, USA. Wetlands 24:212218. https://doi.org/10.1672/0277-5212(2004)024[0212: BIIACA]2.0.CO;2

Stewart TW, Downing JA (2008) Macroinvertebrate communities and environmental conditions in recently constructed wetlands. Wetlands 28:141-150. https://doi.org/10.1672/06-130.1

Straková P, Niemi RM, Freeman C, Peltoniemi K, Toberman H, Heiskanen I, Fritze H, Laiho R (2011) Litter type affects the activity of aerobic decomposers in a boreal peatland more than site nutrient and water table regimes. Biogeosciences 8:2741-2755. https://doi. org/10.5194/bg-8-2741-2011

Tanner CC (1996) Plants for constructed wetland treatment systems - a comparison of the growth and nutrient uptake of eight emergent species. Ecological Engineering 7:59-83. https://doi.org/10.1016/ 0925-8574(95)00066-6

Therneau T, Atkinson B (2018) rpart: Recursive partitioning and regression trees. R package version 4.1-13, https:/CRAN.R-project.org/ package $=$ rpart

Thormann MN (2006) Diversity and function of fungi in peatlands: a carbon cycling perspective. Canadian Journal of Soil Science 86: 281-293. https://doi.org/10.4141/S05-082

Thormann MN, Currah RS, Bayley SE (2003) Succession of microfungal assemblages in decomposing peatland plants. Plant and Soil 250: 323-333. https://doi.org/10.1023/A:1022845604385

Thullen JS, Nelson SM, Cade BS, Sartoris JJ (2008) Macrophyte decomposition in a surface-flow ammonia-dominated constructed wetland: rates associated with environmental and biotic variables. Ecological Engineering 32:281-290. https://doi.org/10.1016/j.ecoleng.2007. 12.003

Tiegs SD, Clapcott JE, Griffiths NA, Boulton AJ (2013) A standardized cotton-strip assay for measuring organic-matter decomposition in streams. Ecological Indicators 32:131-139

Trinder CJ, Johnson D, Artz RRE (2009) Litter type, but not plant cover, regulates initial litter decomposition and fungal community structure in a recolonising cutover peatland. Soil Biology and Biochemistry 41:651-655. https://doi.org/10.1016/j.soilbio.2008.12.006 
Triska FJ, Sedell JR (1976) Decomposition of four species of leaf litter in response to nitrate manipulation. Ecology 57:783-792. https://doi. org/10.2307/1936191

Voellm C, Tanneberger F (2014) Shallow inundation favours decomposition of Phragmites australis leaves in a near-natural temperate fen. Mires and Peat 14:1-9

Voshell JR, Simmons GM (1984) Colonization and succession of benthic macroinvertebrates in a new reservoir. Hydrobiologia 112:27-39. https://doi.org/10.1007/BF00007663

Vymazal J (2007) Removal of nutrients in various types of constructed wetlands. Science of The Total Environment 380:48-65. https://doi. org/10.1016/j.scitotenv.2006.09.014

Weber KP, Legge RL (2011) Dynamics in the bacterial community-level physiological profiles and hydrological characteristics of constructed wetland mesocosms during start-up. Ecological Engineering 37: 666-677. https://doi.org/10.1016/j.ecoleng.2010.03.016
Whatley MH, van Loon EE, Cerli C, Vonk JA, van der Geest HG, Admiraal W (2014) Linkages between benthic microbial and freshwater insect communities in degraded peatland ditches. Ecol Indic 46:415-424. https://doi.org/10.1016/j.ecolind.2014.06.031

Wickham H (2011) The split-apply-combine strategy for data analysis. Journal of Statistical Software 40(1):1-29

Wickham H (2007) Reshaping data with the reshape package. Journal of Statistical Software 21(12):1-20

Wickham H (2009) Elegant graphics for data analysis. Springer Verlag, New York

Zhao X, Zhao Y, Wang J, Meng X, Zhang B, Zhang R, Wang T, Huang N, Wang S, Wang W (2015) Design of a novel constructed treatment wetland system with consideration of ambient landscape. International Journal of Environmental Studies 72:146-153. https://doi.org/10.1080/00207233.2014. 950504 